\title{
THE INFLUENCE OF MARKETING MIX, PERCEIVED RISK, AND SATISFACTION ON WORD OF MOUTH IN XYZ CLINIC
}

\author{
Saka Haditya Murpraptomo ${ }^{1 *}$, Lilik Noor Yuliati², Bagus Sartono ${ }^{3}$ \\ ${ }^{1}$ Management and Business, School of Business, IPB University, 16151 \\ ${ }^{2}$ Department of Family and Consumer Sciences, Faculty of Human Ecology, \\ IPB University, Bogor, 16680 \\ ${ }^{3}$ Department of Statistics, Faculty of Mathematics and Natural Science, \\ IPB University, Bogor, 16680 \\ *Corresponding author: sakashoes@gmail.com
}

\begin{abstract}
The increasing need for health services, peoples who lived in the Pekayon, Bekasi City were given the opportunity to choose the right clinic. Word of mouth is a marketing technique that can be used by clinics. This study aims to analyze the effects of the marketing mix, perceived risk, and satisfaction on word of mouth at XYZ clinic. The research is a descriptive method with a survey using questionnaires and 200 respondents as the sample. Furthermore, the data analysis technique is descriptive with SPSS16.0 software and Structural Equation Model (SEM) with LISREL 8.70. Based on the results, it can be concluded that the marketing mix has a positive effect on perceived risk, marketing mix has a positive effect on satisfaction, perceived risk has a negative effect on satisfaction, marketing mix has a positive effect on word of mouth, perceived risk has a negative effect on word of mouth, and satisfaction has a positive effect on word of mouth. Referring to these conclusions, it can be confirmed that the clinical management of doctor XYZ needs to improve employee services, convenience the patient that this clinic has expert doctors, and utilizing the use of social media as a marketing strategy.
\end{abstract}

Keywords: clinic, marketing mix, perceived risk, satisfaction, word of mouth.

\begin{abstract}
Abstrak
Semakin meningkatnya kebutuhan akan pelayanan kesehatan, masyarakat di daerah Pekayon, Kota Bekasi diberikan kesempatan untuk memilih klinik yang tepat. Word of mouth adalah teknik pemasaran yang dapat digunakan oleh klinik. Penelitian ini bertujuan untuk menganalisis pengaruh marketing mix, persepsi resiko, dan kepuasan terhadap word of mouth di klinik XYZ. Penelitian ini adalah deskriptif dengan survei menggunakan kuesioner. Penelitian ini menggunakan sampel 200 responden. Teknik analisis data dalam penelitian ini adalah deskriptif dengan software SPSS16.0 dan Structural Equation Model (SEM) dengan software LISREL 8.70. Berdasarkan hasil penelitian, dapat disimpulkan bahwa marketing mix berpengaruh positif terhadap persepsi resiko, marketing mix berpengaruh positif terhadap kepuasan, persepsi resiko berpengaruh negatif terhadap
\end{abstract}


kepuasan, marketing mix berpengaruh positif terhadap word of mouth, persepsi resiko berpengaruh negatif terhadap word of mouth, dan kepuasan berpengaruh positif terhadap word of mouth. Mengacu pada kesimpulan ini, dapat dipastikan bahwa manajemen klinik XYZ perlu meningkatkan layanan karyawan, meyakinkan pasien bahwa klinik ini memiliki dokter ahli, dan memanfaatkan penggunaan media sosial sebagai strategi pemasaran.

Kata Kunci: klinik, kepuasan, marketing mix, persepsi resiko, word of mouth.

\section{Introduction}

In daily basis activities, health is the primary issue but, changes in unhealthy lifestyles particularly in urban areas have a weight on health. The clinic is one of the health infrastructures that is facilely found in sundry regions, including in densely populated housing. When someone goes to a doctor or clinic, they cannot check the quality of each clinic or doctor because they do not have the time or resources, thus someone admit recommendations from their family, friends, or closest people.

One of the marketing strategies is word of mouth. Word of mouth plays an important role for it is essential for brands, organizations, or businesses that have a small budget in marketing their products or services because they require minimal costs compared to use advertising media. People who did word of mouth usually derived by the satisfaction either facilities or services. Thus, satisfaction plays a huge role in word of mouth marketing.

According to Kotler and Keller (2012), high satisfaction makes someone voluntarily spread word of mouth in the form of good news about the company. In addition to satisfaction, risk perception is something that needs to be considered in word of mouth. According to Martin (2017) risk perception theory adds an important aspect that helps to understand information derived from word of mouth and its effects. Also, from the aspect of service providers, the marketing mix needs to be considered in building positive word of mouth. This is important because the marketing mix framework is widely used by marketers as the foundation of marketing planning by marketing practitioners as a universal marketing paradigm (Cengiz and Yayla, 2007).

Based on prior explanation, previous studies and theories had explained word of mouth, satisfaction, risk perception, and marketing mix, yet none of the researchers nowadays has combined these variables for study in the field of health services, mainly clinics. One of the clinics located in Pekayon, Kota Bekasi is the XYZ Clinic which was established in 2004 withstand until now and developing with plans to create inpatient care facilities. One the predictor has been thought what makes XYZ clinic able to survive and continue to grow is through word of mouth marketing techniques to patients by favoring quality services. Although using word of mouth techniques, the average number of patients treated at this clinic only 60-80 patients per day, while the target is 100 patients per day (Figure 1). There are fluctuations of visitor every year and tends to decrease. The most significant decrease was September to November of 2017. This study aims to analyze the effect of the marketing

mix, risk perception, and satisfaction with word of mouth in the XYZ clinic and formulate managerial implications that can be applied to the health industry, especially clinics. 


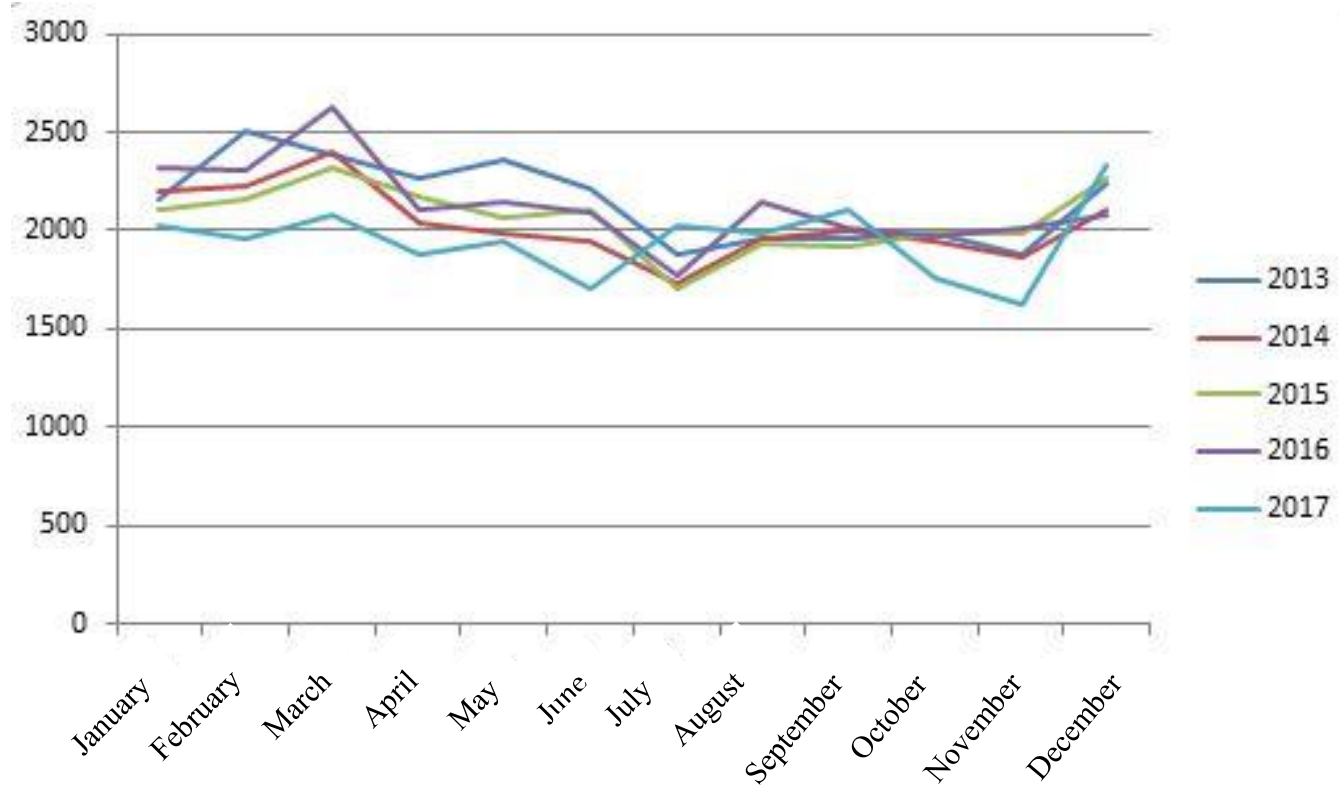

Figure 1. Visitors of XYZ clinic in 2013-2017

Various theories related to the variables studied include; marketing mix has a negative effect on risk perception (Yoon, 2010), the marketing mix has a significant effect on satisfaction (Alipour and Darbahaniha, 2018), negative relationship between risk perception and customer satisfaction (Ghotbabadi et al., 2016), product, price, promotion, personnel, process, and physical evidence affect word of mouth (Syriac, 2013), there is a negative link between risk perception and word of mouth (Tho et al., 2017), satisfaction significantly and positively affects word of mouth (Hsu, 2018; Simanjuntak \& Hamimi, 2019). The conceptual framework of research can be seen in Figure 2.

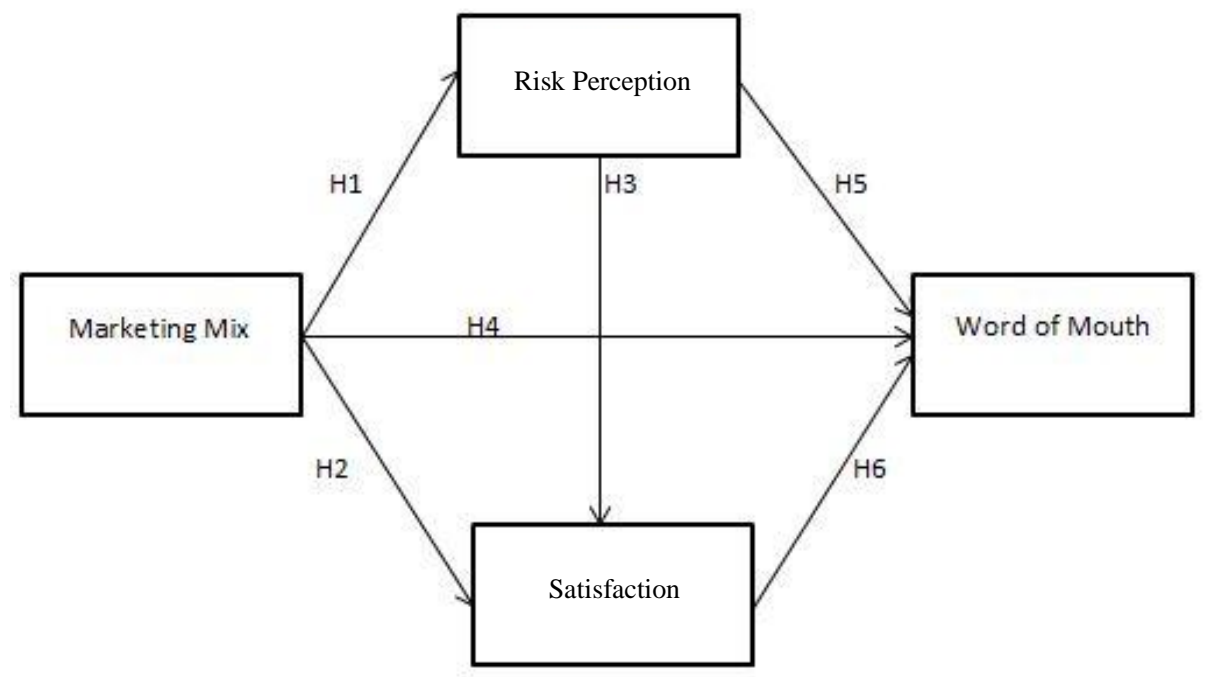

Figure 2. Conceptual Framework 
1. H1: Marketing mix has a significant effect on risk perception

2. H2: Marketing mix has a significant effect on satisfaction

3. H3: Risk perception has a significant effect on satisfaction

4. H4: Marketing mix has a significant effect on word of mouth

5. H5: Risk perception has a significant effect on word of mouth

6. H6: Satisfaction has a significant effect on word of mouth

\section{Methods}

The research was located in XYZ clinic in Bekasi City, Indonesia. The study was conducted for three months starting from July 2018 to September 2018. Using a quantitative approach with survey methods, and involving XYZ clinic patient as the respondents. This study used convenience sampling techniques or often called accidental sampling with the criteria of respondents are patients at the XYZ clinic general polyclinic who have treated at least once. The technique is advantageous as it takes relatively little time and cheaper costs (Sumarwan, 2014).

The variables of this study are word of mouth, satisfaction, risk perception, and marketing mix. In this study, the definition of word of mouth variable is sharing information through face to face or social media consisting of five indicator variables. The second variable is satisfaction which is interpreted as the patient's assessment of the quality of service consists of three indicator variables. The third variable is the perception of risk, a concern that can arise when having a treatment at the XYZ clinic, consists of five dimensions (financial, performance, psychological, physical, time), each dimension has two indicators. The last variable is the marketing mix as a value offered by the XYZ clinic, consisting of seven dimensions, namely; product, price, place, promotion, process, each dimension consists of two indicators, while the physical and personnel dimensions each have three indicators. According to Ferdinand (2005), the sample size is 5 to 10 times of the number indicator variables, so the number of samples is between $34 \times 5=170$ people up to $34 \times 10$ $=340$ people. This study used a total sample of 200 people. The data collected in this study were primary data obtained from the main source, by providing self-administered questionnaires. The data then analyzed by descriptive statistical methods, and Structural Equation Modeling (SEM). Descriptive statistics are used to see patient demographic and behavioral characteristics (service, clinic, and social media). SEM analysis is used to analyze the influence between the variables of the marketing mix, perceived risk, and satisfaction of word of mouth.

\section{Findings}

\section{Respondents' Characteristics}

The sample of this study was the XYZ Clinic patients in Bekasi City. Questions about demographics were given, namely gender, age, education, job, and monthly household expenses. Distribution of respondents by sex are respondents with female sex $(51.5 \%)$ more than male respondents (48.5\%). Then, the age category of 25-35 years is the highest number of respondents with 67 people or 33.5 percent. Characteristics of respondents based on 
education were dominated by high school level with a total of 90 people or 45.0 percent, jobs that had the highest number of respondents were private employees with 81 people or 40.5 percent, and expenditure categories of household respondents per month with the highest number of 118 respondents or 59.0 percent for the IDR 1.500.000- IDR 5.000.000.

Table 1.Respondents' characteristics

\begin{tabular}{llrr}
\hline Characteristics & Category & Total (n) & Percentage (\%) \\
\hline Gender & Male & 97 & 48.5 \\
& Female & 103 & 51.5 \\
Age (years) & & & 24.0 \\
& $17-24$ & 48 & 33.5 \\
& $25-35$ & 67 & 18.0 \\
& $36-45$ & 36 & 11.5 \\
& $46-55$ & 23 & 13.0 \\
Education & $>55$ & 26 & 5.0 \\
& & & 10.5 \\
& Elementary & 10 & 45.0 \\
& Junior High School & 21 & 18.0 \\
& Senior High School & 90 & 21.0 \\
& Diploma & 36 & 0.5 \\
Job & Bachelor & 42 & 12.5 \\
& Master/Doctoral & 1 & 26.0 \\
& & & 17.0 \\
& Student & 25 & 40.5 \\
& Not Employee & 52 & 2.5 \\
& Entrepreneur & 34 & 1.5 \\
Household & Employees & 81 & \\
Month & State Employee & 5 & 34.0 \\
& Others & 3 & 59.0 \\
& & & 6.0 \\
& LIDR.500.000 & 68 & 1.0 \\
\hline
\end{tabular}

\section{Social Media Use Behavior}

Based on the study, it was found that as many as 179 people or 89.5 percent of respondents were active users in social media for the past 3 months, and 21 people or 10.5 percent of respondents were not active in using social media. This illustrates that social media can be a communication tool used by the majority of respondents. Based on the results of the questionnaire that was distributed multi-response, the social media that respondents often use is Whatsapp, which is 163 people or 81.5 percent, second place is Facebook as many as 64 people or 32.0 percent, followed by Instagram which is 57 people or 28.5 percent. This finding in line with Simanjuntak and Musyifah (2016) that social media accounts owned by consumers most widely are Line (98\%), Facebook (95\%), Twitter (93\%), BBM or Blackberry Messenger (93\%), Whatsapp (90\%), and Instagram (90\%). 


\section{Overall Model Fit}

The model fit test can be seen from the complete Root Mean Square Residual/RMR, Root Mean Square Error of Approximation/RMSEA, Goodness of Fit Index/GFI, Adjusted Goodness of Fit Index/AGFI, Normed Fit Index / NFI, Comparative Fit Index / CFI and Relative Fit Index/RFI in Table 2. The overall value of the aspects of the conformity criteria has been included in the Good Fit category so that the overall research model is declared feasible. The results obtained after re-specification, indicate that the overall model fit is included in the Good Fit category.

Table 2. Overall Model Fit Results

\begin{tabular}{llrrr}
\hline & \multicolumn{1}{c}{ Goodness-Of-Fit } & \multirow{2}{*}{ Cut-off-Value } & \multicolumn{2}{c}{ Eliminated } \\
\cline { 4 - 5 } & & $\leq 0.10$ & Result & Note \\
\hline 1. & Root Mean Square Residual (RMR) & $\leq 0.08$ & 0.05 & Good Fit \\
2. & Root Mean Square Error of Approximation & $\geq 0.90$ & 0.95 & Good Fit \\
& (RMSEA) & $\geq 0.90$ & 0.91 & Good Fit \\
3. & Goodness Of Fit Index (GFI) & $\geq 0.90$ & 0.93 & Good Fit \\
4. & Adjusted Goodness Of Fit Index (AGFI) & $\geq 0.90$ & 0.91 & Good Fit \\
5. & Normed Fit Index (NFI) & $\geq 0.90$ & 0.92 & Good Fit \\
6. Comparative Fit Index (CFI) & & & \\
7. & Relative Fit Index (RFI) & & \\
\hline
\end{tabular}

\section{Measurement Model Fit}

The suitability test of the measurement model was carried out by validity and reliability (Table 3). The results of the validity test show that not all indicators have a t-value of more than 1.96 and the coefficient $>0.5$. In the marketing mix variable, the dimensions of personnel and physical evidence each have one invalid indicator. As for risk perception variables, the financial, performance, and physical dimensions each have one invalid indicator, and for word of mouth variables, only one indicator is invalid.

Table 3. Construct reliability (CR) and variance extracted (VE) values

\begin{tabular}{llcc}
\hline Latent Variables & Indicators & CR & VE \\
\hline 1. Marketing Mix (MM) & MMPD - MMPH & 0.96 & 0.53 \\
Product (MMPD) & MMPD 1 - MMPD 2 & 0.73 & 0.50 \\
Price (MMPR) & MMPR 1 - MMPR 2 & 0.78 & 0.64 \\
Place (MMPL) & MMPL 1 - MMPL 2 & 0.77 & 0.54 \\
Promotion (MMPM) & MMPM 1 - MMPM 2 & 0.71 & 0.41 \\
Personnel (MMPE) & MMPE 1 - MMPE 3 & 0.73 & 0.50 \\
Process (MMPS) & MMPS 1 - MMPS 2 & 0.83 & 0.50 \\
Physical Evidence (MMPH) & MMPH 1 - MMPH 3 & 0.76 & 0.59 \\
2. Risk Perception (PR) & PRFN - PRTM & 0.93 & 0.68 \\
Financial (FN) & PRFN 1 - PRFN 2 & 0.72 & 0.51 \\
Performance (PF) & PRPF 1 - PRPF 2 & 0.72 & 0.58 \\
Psychological (PS) & PRPS 1 - PRPS 2 & 0.73 & 0.90 \\
Physical (FI) & PRFI 1 - PRFI 2 & 0.75 & 0.82 \\
Time (TM) & PRTM 1 - PRTM 2 & 0.75 & 0.58 \\
3. Satisfaction (ST) & ST1 - ST3 & 0.79 & 0.36 \\
4. Word of Mouth (Y) & Y1 - Y5 & 0.85 & 0.52 \\
\hline
\end{tabular}


Based on Table 3, marketing mix, risk perception, satisfaction, and word of mouth meet reliable requirements with Construct Reliability $(\mathrm{CR})>0.7$. That is, all the variables and indicators have represented well the latent constructs developed. This indicates that each indicator variable is valid for measuring its latent construct. Based on the table above, the value of the Variance Extracted (VE) of the marketing mix, the perceptions of income and word of mouth $\geq 0.50$. The Variance Extracted (VE) value of satisfaction shows $<0.5$ but, still has construct reliability $(\mathrm{CR})>0.6$, then the Convergent Validity of the latent construct can still be said to be sufficient.

\section{Structural Model Fit}

The next step that must be done is to test the suitability of the structural model fit. In the initial testing phase, the MMPE3, MMPH3, PRFN1, PRPF1, PRFI2 and Y5 indicators included indicators that did not have good validity so that these variables were not included in the next processing phase, namely the validity test. Figure 3 shows SEM measurement model.

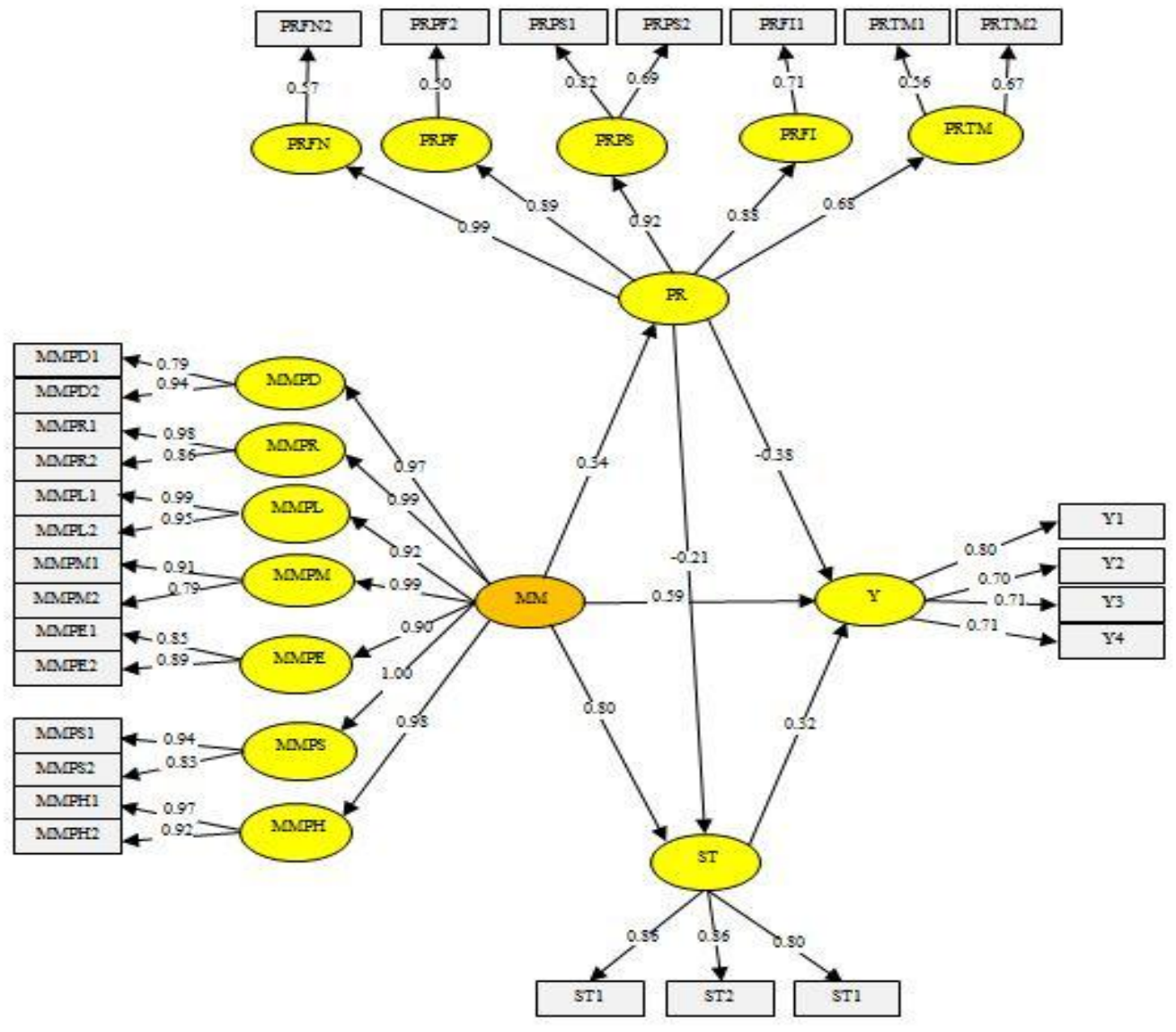

Figure 3. SEM Measurement Model 
By using LISREL, the word of mouth variable has a value of $\mathrm{R}^{2}=0.56$ which means that the percentage effect of satisfaction, risk perception and marketing mix variables on word of mouth variables is 56.0 percent or can be interpreted as variations in satisfaction, risk perception, and marketing mix used in the model is able to explain 56.0 percent of the variation of word of mouth variables, while the remaining 44.0 percent is influenced or explained by other variables not included in the research model such as service value variables in Hsu's research (2018), or loyalty such as Cengiz and Yayla's research (2007).

\section{Statistical Hypothesis Test}

In testing the hypothesis, if the path coefficient value $>0.05$ with the value of t-value $>1.96$ then the influence of certain variables is included in the significant category, but if the value of the path coefficient $<0.05$ with $t$-value $<1.96$ then the influence between variables included in the non-significant category (Table 4).

Table 4. Statistical hypothesis test

\begin{tabular}{lllcccc}
\hline Variables & & & Coefficient & t-value & Conclusion & Note \\
\hline Marketing mix & $\rightarrow$ & Risk Perception & 0.34 & 4.75 & Significant & Accept $\mathrm{H}_{1}$ \\
Marketing mix & $\rightarrow$ & Satisfaction & 0.80 & 10.67 & Significant & Accept $\mathrm{H}_{2}$ \\
Risk Perception & $\rightarrow$ & Satisfaction & -0.21 & 3.03 & Significant & Accept $\mathrm{H}_{3}$ \\
Marketing mix & $\rightarrow$ & Word of mouth & 0.59 & 6.72 & Significant & Accept $\mathrm{H}_{4}$ \\
Risk Perception & $\rightarrow$ & Word of mouth & -0.38 & 5.45 & Significant & Accept $\mathrm{H}_{5}$ \\
Satisfaction & $\rightarrow$ & Word of mouth & 0.32 & 4.63 & Significant & Accept $\mathrm{H}_{6}$ \\
\hline
\end{tabular}

Table 4 explains that all influences between variables have a significant effect, such as the positive influence of marketing mix on risk perception, marketing mix has a positive effect on satisfaction, risk perceptions negatively affect satisfaction, marketing mix has a positive effect on word of mouth, risk perception negatively influences word of mouth, and satisfaction has a positive effect on word of mouth.

In addition to direct influence, this study also has an indirect influence. Indirect effects on this study include marketing mix (MM) effect on word of mouth (Y) through risk perception (PR), marketing mix (MM) effect on word of mouth (Y) through satisfaction (ST), marketing mix (MM) effect on satisfaction (ST) through perceptions of risk (PR) and risk perception (PR) influence on word of mouth (Y) through satisfaction (ST). Table 5 explains the indirect effects.

Table 5. Indirect influence and total influence between variables

\begin{tabular}{|c|c|c|c|c|c|c|}
\hline \multicolumn{5}{|c|}{ Indirect Effects } & \multirow{2}{*}{$\begin{array}{c}\text { Loading } \\
\text { factor } \\
-0.13\end{array}$} & \multirow{2}{*}{$\begin{array}{c}\begin{array}{c}\text { Total } \\
\text { influence }\end{array} \\
0.46\end{array}$} \\
\hline Marketing Mix & $\rightarrow$ & Perceived Risk & $\rightarrow$ & Word of Mouth & & \\
\hline Marketing Mix & $\rightarrow$ & Satisfaction & $\rightarrow$ & Word of Mouth & 0.26 & 0.85 \\
\hline Perceived Risk & $\rightarrow$ & Satisfaction & $\rightarrow$ & Word of Mouth & 0.07 & -0.31 \\
\hline Marketing Mix & $\rightarrow$ & Perceived Risk & & Satisfaction & -0.07 & 0.73 \\
\hline
\end{tabular}

The indirect influence of the marketing mix on word of mouth through perceived risk is -0.13 while the direct effect of the marketing mix on word of mouth is 0.59 . The direct 
effect of the marketing mix on word of mouth has a greater influence. In addition, the indirect effect makes the path coefficient negative. The amount of indirect influence of the marketing mix on word of mouth through satisfaction is 0.26 while the direct effect of the marketing mix on word of mouth is 0.59 . Although the direction of both is the same, the direct influence has a higher path coefficient so that the influence is more significant when compared to the indirect influence of the marketing mix on word of mouth. The magnitude of the indirect effect of risk perception on word of mouth through satisfaction is 0.07 , while the direct influence of risk perceptions on word of mouth is -0.38 , thus the direct influence of risk perceptions on word of mouth has a greater influence. In addition, indirect influence makes the path coefficient positive. The amount of indirect influence from the marketing mix on satisfaction through risk perception is -0.07 while the direct effect of the marketing mix on satisfaction is 0.80 , therefore the direct influence of marketing mix on satisfaction has a greater influence. Besides, indirect effects make the path coefficient negative.

\section{Discussion}

\section{Effects of Marketing Mix on Risk Perception}

The first hypothesis, namely the marketing mix has a significant effect on risk perception. This can be seen from the marketing mix path coefficient on the perception of risk of 0.34 with t-count of 4.75 . So that it can explain that the marketing mix variable has a positive and significant effect on risk perception thus it accepts the first hypothesis. The positive effect of the marketing mix on risk perception, in a previous study conducted by Yoon (2010) found a negative influence between marketing mix and risk perception.

\section{Effects of the Marketing mix on Satisfaction}

The second hypothesis, which states that the marketing mix has a significant effect on satisfaction. The link in between variables can be seen from the path coefficient of the marketing mix to satisfaction of 0.80 with $t$-value of 10.67 . This can explain that the marketing mix variable has a positive and significant effect on satisfaction so that it accepts the second hypothesis. This result is supported by previous research conducted by Alipour and Darbahaniha (2018) which shows that the 7P marketing mix element consisting of product, price, place, promotion, personnel, process, and physical evidence has a significant influence on satisfaction.

\section{Effects of Risk Perception on Satisfaction}

The third hypothesis, states that perceptions of risk have a significant effect on satisfaction. This can be seen from the perception of risk to satisfaction path coefficient of 0.21 with t-value of 3.03 . So, it can explain that the risk perception variable has a negative and significant effect on satisfaction so that it accepts the third hypothesis. Risk perception negatively influences satisfaction. This result is supported by previous research conducted by Ghotbabadi et al. (2016); Yue Chen et al. (2015); Cheng and Lee (2011). 


\section{Effects of the Marketing mix on Word of Mouth}

The examination of the fourth hypothesis shows the marketing mix has a positive and significant effect on word of mouth. This can be seen from the marketing mix path coefficient on word of mouth at 0.59 with t-value of 6.72 . This can explain that the marketing mix variable has a positive and significant effect on word of mouth so that it accepts the fourth hypothesis which states the marketing mix has a significant effect on word of mouth. This result is supported by previous research conducted by Suryani (2013) which explains that product, price, promotion, personnel, process, and physical evidence affect word of mouth; Cengiz and Yayla (2007) show that the components of the marketing mix, namely product, price, promotion, and place.

\section{Effects of Risk Perception on Word of mouth}

The results of examining the fifth hypothesis show that perception of risk negatively and significantly affects word of mouth. This can be seen from the path coefficient of perception of risk for word of mouth at -0.38 with t-value of 5.45 . This can explain that the risk perception variable has a negative and significant effect on word of mouth so that it accepts the fifth hypothesis which states risk perceptions have a significant effect on word of mouth. Previous research by Tho et al. (2017) found that there was a negative relationship between perceived risk and word of mouth.

\section{Effects of Satisfaction on Word of Mouth}

The test of the sixth hypothesis shows satisfaction has a positive and significant effect on word of mouth. This can be seen from the path coefficient of satisfaction with word of mouth at 0.32 with t-value of 4.63 meaning that it accepts the hypothesis. Prior research whose supporting this result are Hsu (2018); Kitapci et al. (2014); Chaniotakis and Lymperopoulos (2009); Cengiz and Yayla (2007).

\section{Managerial Implications}

Actions that should be taken by the $\mathrm{XYZ}$ clinic are the promotion of consultation (creating events to regarding diseases that are often found in the community), expanding parking lots, mind the hospitality of employees (enforcing a standard smile, greetings, greeting). Meanwhile, to minimize the risk/concern of patients by increasing physician care qualifications, increasing the number of employees. Besides that, it is necessary to do a family approach because the source of information trusted by patients is from the closest people like family/friends/neighbors. This can be improved by utilizing social media accounts that are quite popular based on this research such as Whatsapp, Facebook, Instagram.

\section{Conclusion and Recommendation}

\section{Conclusion}

Marketing mix, perceived risk, and satisfaction have an influence on word of mouth. This can be seen from significant research results such as; marketing mix has a positive effect 
on risk perception, marketing mix has a positive effect on satisfaction, risk perception has a negative effect on satisfaction, marketing mix has a positive effect on word of mouth, risk perception has a negative effect on word of mouth, and satisfaction has a positive effect on word of mouth hypothesis accepted. Referring to these conclusions, it can be implied that $\mathrm{XYZ}$ clinic management needs to improve employee services, assure patients that the clinic has expert doctors including duty doctors on duty, and utilize the use of mainstream social media such as Whatsapp, Facebook, and Instagram to share information.

\section{Recommendation}

This study only discusses the general polyclinic in the XYZ clinic, not including specialist medical services or larger scale such as hospitals. The questionnaire used is a standard questionnaire, but the questionnaire was independently developed by researchers based on research theory and concepts so that there are several indicators that are invalid and then omitted in SEM calculations. In addition, a compilation of data retrieval is also very dependent on this study, the study respondents were patients who were sick and were waiting for doctor's services at the XYZ clinic or the patient's family to take respondents who were waiting, busy and less focused in filling out the research. This factor makes it difficult for researchers to get good answers.

Suggestion for further research is to conduct detailed research on the relationship of the marketing mix in the services/services (product, price, place, promotion, personnel, process, and physical evidence) with risk perceptions especially in the field of health. In this study, the marketing mix has a positive effect on risk perception. This is beyond the prediction that the marketing mix has a negative effect on risk perception. Further research should add indicator variables from the financial, performance, psychological, physical, time-varying dimensions related to perceived risk and add the social dimension of the risk perception variable. This is because respondents prefer to answer neutral rather than giving a good or bad assessment, if further research adds variations in variable indicators it is expected to reduce the answers that are still biased.

\section{References}

Al Badi, K.S. (2015). The Dimensions of Marketing Mix. Journal of Management and Organizational Studies, 2(1),136-142.

Alipour, M., Pour, B.M., Darbahaniha, A. (2018). The Effects of the 7P Marketing Mix Components on Sporting Goods Customer Satisfaction. International Journal of Business and Management Invention, 7(1),20-26.

Argan, M. (2012). Word-of-Mouth (WOM) as A Tool of Health Communication: A Case Study of Turkey. Journal of Society for development in new net environment in $B \& H$, 6(1),216-221.

Cengiz, E., Yayla, H.E. (2007). The effect of marketing mix on positive word of mouth communication: evidence from accounting offices in Turkey. Innovative Marketing Journal, 3(4),74-86.

Chaniotakis, I.E., Lymperopoulos, C. (2009). Service quality effect on satisfaction and word of mouth in the health care industry. Journal of Managing Service Quality, 19(2), 229242. 
Chun Hsu, L. (2018). Investigating Effect of Service Encounter, Value, and Satisfaction on Word of Mouth: An Outpatient Service Context. International Journal of Environment Research and Public Health, 132,1-15.

Feng Cheng, F., Hsuan Lee, A. (2011). The influences of relationship marketing strategy and transaction cost on customer satisfaction, perceived risk, and customer loyalty. African Journal of Business Management, 5(13), 5199-5209.

Ferdinand, A. (2005). Structural Equation Modeling dalam Penelitian Manajemen (Aplikasi Model-Model Rumit dalam Penelitian untuk Tesis Magister dan Disertasi Doktor).Ed ke-2. Semarang (ID):Fakultas Ekonomi UNDIP.

Ghotbabadi, A.R., Feiz, S., Baharun, R. (2016). The Relationship of Customer Perceived Risk and Customer Satisfaction. Mediterranean Journal of Social Sciences,7(1),161173.

Kitapci, O., Akdogan, C., Dortyol, I.T. (2014). The Impact of Service Quality Dimensions on Patient Satisfaction, Repurchase Intentions and Word-of-Mouth Communication in the Public Healthcare Industry. Procedia-Social and Behavioral Sciences,148,161169.

Kotler, P., Keller, K.L. (2012). Marketing Management 14th edition. New Jersey (US). Prentice Hall.

Martin, S. (2017).Toward a Model of Word-of-Mouth in the Health Care Sector, Journal of Nonprofit \& Public Sector Marketing, 29(4),434-449.

Simanjuntak, M., Musyifah, I. (2016) Online Shopping Behavior on Generation Y in Indonesia. Global Business Finance Review. 21 (1): 33-45. http://dx.doi.org/Http://dx.doi.org/10.17549/gbfr.2016.21.1.33.

http://sipakaril.ipb.ac.id/Files/bd983853-72e6-4fba-a863-

95a0496acc4b/paper_bd983853-72e6-4fba-a863-95a0496acc4b.pdf

Simanjuntak, M., Hamimi, U.K. (2018). Penanganan Komplain dan Komunikasi Word-ofMouth (WOM). Jurnal Ilmu Keluarga dan Konsumen. 12 (1): 75-86. http://dx.doi.org/10.24156/jikk.2019.12.1.75.

http://jurnal.ipb.ac.id/index.php/jikk/article/view/25268/16438

Sumarwan, U. (2014). Metode Riset Bisnis dan Konsumen.Bogor (ID).IPB Press

Suryani. (2013). Analisis Faktor Bauran Pemasaran yang Mempengaryuhi kepuasan Nasabah Sehingga Tercipta Word of Mouth Positif di PT.Bank Muamalat Indonesia,Tbk Cabang Medan. INFERENSI, Jurnal Penelitian Sosial Keagamaan, 7(1),143-162.

Tho, N.X., Lai, M.T., Yan, H. (2017). The Effect of Perceived Risk on Repurchase Intention and Word - of -Mouth in the Mobile Telecommunication Market:A Case Study from Vietnam. International Business Research,10(3),8-19.

Yoon, T.H. (2010). Influence of Service Marketing-Mix(7Ps) on Consumers' Risk Perception of Eating at Family Restaurants in Seoul.Korean Journal Food Cookery Science,26(5),511-520.

Yue Chen, Yan, X., Fan,W., Gord, M.D. (2015). The joint moderating role of trust propensity and gender on consumers'online shopping behavior. Computers in Human Behavior, 4(3): 272-283. 